SAINS TANAH - Journal of Soil Science and Agroclimatology

Journal homepage: http://jurnal.uns.ac.id/tanah

\title{
Soil fertility status and sweet potato cultivation in composted mounds under humid lowland tropical climatic conditions
}

\author{
Patrick S. Michael* \\ Department of Agriculture, PNG University of Technology, Papua New Guinea
}

\begin{tabular}{|c|c|}
\hline ARTICLE INFO & ABSTRACT \\
\hline $\begin{array}{l}\text { Article history } \\
\text { Submitted: 2020-07-31 } \\
\text { Accepted: 2020-12-17 } \\
\text { * Corresponding Authors } \\
\text { Email address: } \\
\text { patrick.michael@pnguot.ac.pg }\end{array}$ & $\begin{array}{l}\text { The importance of organic matter addition in composted mounds in terms of nutrients } \\
\text { status, nutrient uptake, and environmental impact under different climatic conditions } \\
\text { need to be studied. This study was conducted to assess the importance of Cogon grass } \\
\text { materials addition as organic matter in composted mounds used for sweet potato } \\
\text { cultivation on selected sandy loam soil properties under humid lowland, tropical climatic } \\
\text { conditions. A replicated trial with four treatments with or without organic matter or sweet } \\
\text { potato plants was set in a completely randomized design. After } 6 \text { months, soil samples } \\
\text { were collected from two profiles in each treatment and analyzed for selected soil } \\
\text { physiochemical properties. Data collected from each profile was pooled, averages taken, } \\
\text { and statistically analyzed. The results showed organic matter addition increased water } \\
\text { holding capacity and electrical conductivity, lowered soil bulk density, pH, and soil organic } \\
\text { carbon content. Cultivation of sweet potato in soil with or without organic matter } \\
\text { amendment, in general, depleted nitrogen, potassium, and magnesium contents and } \\
\text { increased phosphorous availability. This study showed the addition of Cogon grass } \\
\text { materials as organic matter in composted mounds has implications for the production of } \\
\text { sweet potato in sandy loam soil in the tropics. }\end{array}$ \\
\hline
\end{tabular}

How to Cite: Michael, P. S. (2020). Soil fertility status and sweet potato cultivation in composted mounds under humid lowland tropical climatic conditions. Sains Tanah Journal of Soil Science and Agroclimatology, 17(2): 144-151 (doi: 10.20961/stjssa.v17i2.43426)

\section{Introduction}

In the highlands of Papua New Guinea (PNG), composted mounds (Fig. 1) are used to cultivate sweet potato (Ipomoea batatas Lam.). In this practice, a heap of organic matter that resembles a cone shape is made on the soil surface in rows, covered with soil then vines of sweet potato are manually planted (Floyd et al., 1988). The mounds allow permanent land use, intercropping, and multiple harvesting, making sweet potato a strategic crop for food security (Taraken \& Ratsch, 2009). Environmentally, the structure of the mound counteracts the risks of flooding, soil-borne diseases, and reduces soil erosion (Schulz \& Glaser, 2012). The practice also offsets the inherent loss of soil fertility by utilizing organic materials (Pérez-Piqueres et al., 2006), such as garden debris, grasses, and farmyard manure as compost (widely available and relatively cheap compared to inorganic fertilizers). The structure of the mounds depends on the amount of organic matter addition and varies in the traditional composted mound making areas in PNG. Several earlier studies were conducted to evaluate the importance of composted mounds on sweet potato yield (D'Souza \& Bourke, 1982), and the benefits, in particular, are well-documented (e.g. Tiquia et al., 1996; Tilston et al., 2002; Tiquia, 2010). Even studies dealing with composting of wastes from an agricultural and ecological perspective (Tuitert et al., 1998; Tuomela et al., 2000; Weber et al., 2007), including the phytotoxicity concerns resulting from the decomposition processes of composting of organic matter (Tiquia, 2010) are available.

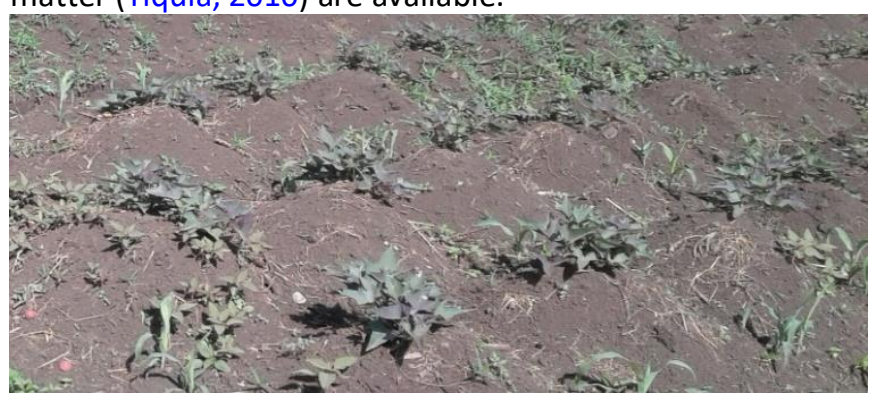

Figure 1. Composted mounds in lower highlands of PNG (Michael, P. S., 2019). 
What is not widely studied and reported, especially in the humid tropics, are concurrent composting of organic matter and cultivation of food crops, which has agricultural, ecological, and environmental implications. In addition, studies investigating the beneficial effects of the composted mound in terms of (i) nutrients status, (ii) how and which nutrients are taken up, (iii) how and which nutrients are converted to plant growth, or stored in the tubers, and (iv) whether a composted mound has negative impacts on the environment, e.g. from methane emission from decomposition and leaching of nutrients, are lacking in the literature. This study, therefore, was conducted to investigate the importance of organic matter in composted mounds for soil fertility management and the production of sweet potatoes.

\section{Materials and Method}

\subsection{Description of the study site}

The study was conducted at PNG University of Technology, Lae, Morobe Province, PNG $\left(6^{\circ} 42^{\prime} 55.89^{\prime \prime} \mathrm{S}\right.$; $\left.146^{\circ} 59^{\prime} 59.66^{\prime \prime} \mathrm{E}\right)$. The farm from which the soil samples were collected is located at an altitude of $65 \mathrm{~m}$ above sea level (6 $\left.61^{\prime \prime} \mathrm{S} ; 146^{\circ} 98^{\prime \prime} \mathrm{E}\right)$. The mean annual rainfall is up to 3,800 $\mathrm{mm}$, fairly distributed throughout the year. The average daily temperature is $26.3^{\circ} \mathrm{C}$, with an average daily minimum of $22.9{ }^{\circ} \mathrm{C}$ and a maximum of $29.7{ }^{\circ} \mathrm{C}$, respectively. Annual evaporation (US Class A pan) is 2,139 $\mathrm{mm}$ and rainfall exceeds evaporation each month. The climate is classified as Af (Koppen), i.e. a tropical rainy climate that exceeds $60 \mathrm{~mm}$ rain in the driest month. The soil is well drained, derived from alluvial deposits, and is classified as a sandy, mixed, isohyperthermic, Typic Tropofluents (US Soil Taxonomy), or Eutric Fluvisol (World Reference Base) (Aipa \& Michael, 2019; James Aipa \& Michael, 2018; Michael, P.S., 2019).

\subsection{Sample collection}

A stripping method was used to collect soil samples from the 0-300 mm surface (Michael, P. S., 2019). Several buckets full of this soil were collected and taken to the greenhouse where the experiment was conducted. Prior to setting the experiment, all the soil was carefully emptied on a canvas placed on a smooth concrete surface inside the greenhouse and homogenized by mixing using a spade. The homogenous soil was equally spread on the canvas and air-dried for $3 \mathrm{~h}$ under greenhouse conditions. The air-dried soil was sieved using a $0.5 \mathrm{~mm}$ sieve to remove coarse materials including plant matter and repeated until sufficient amounts of soil, adequate for setting the whole experiment were obtained.

\subsection{Organic matter}

To use as organic matter (henceforth referred to as OM), leaves of Cogon grass (Imperata cylindrica L.) were collected (unbiased) from the same site of the farm where the soil was collected. Because of the unbiased collection, older or dead leaves that were collected together were not removed, mimicking a scenario similar to the practice carried out by sweet potato farmers in the highlands of PNG in making composted mounds. These plant materials were brought to the greenhouse, sun-dried on a metal bench for three days, and then chopped into small pieces of equal size $(50 \mathrm{~mm})$ and oven-dried at $70{ }^{\circ} \mathrm{C}$ for 4 days. The brittle plant materials were collected and ground using a 7-speed grinder and kept dry until use.

\subsection{Planting material}

Sweet potato vines, nearly $150 \mathrm{~mm}$ long were collected from the farm and used as propagules. All the vines were collected from a single variety and plant characteristics such as the length, number of leaves per vine, and age were uniform. A sampling of vines was done when the temperature was cooler and immediately planted to avoid desiccation and infection. Dead vines in the planted treatments were replaced with fresh ones within the first two weeks. All vines were planted within 10-20 mm of soil using a small dibble and soil around the vines was pressed to enhance the contact of soil to the vines.

\subsection{Experimental treatments}

The OM was mixed with the soil in bulk (5:1 soil: OM w/w) and several polythene pots $(190 \mathrm{~mm}$ in height and $200 \mathrm{~mm}$ in diameter) were potted with the mix. Potting was made such that a small hill (cone shape) was created in the middle, resembling the cone shape of composted mounds (Fig. 1). The mixed soil is hereafter referred to as amended soil. The unamended soil is henceforth referred to as natural soil. A total of four treatments with each polythene pot containing approximately $1200 \mathrm{~g}$ of soil mix (1000 g soil and $200 \mathrm{~g} \mathrm{OM}$ ) were set:

(i) The first treatment was set as control using natural soil no amendment or planting.

(ii) The second treatment was set using amended soil and not planted.

(iii) The third treatment was set using natural soil and planted.

(iv) The fourth treatment was set using the amended soil and planted.

In all the planted treatments, three vines were planted on the hill (the cone shape resembling a mound). The treatments were replicated four times (a total of 16 polythene pots) and set up in a completely randomized design (CRD) under greenhouse conditions. Each treatment was carefully watered twice a day using tap water throughout for 45 days. All the plants were fully-grown but not mature enough to produce tubers since most sweet potato species in the tropics mature within 95-105 days, the period being longer in the cooler highlands. Out of the four replicates, only three were used for data collection. The fourth replicate was kept as security.

\subsection{Sampling}

A core sampler $(2000 \mathrm{~mm}$ in length and $500 \mathrm{~mm}$ in diameter) was manually driven into the soil in the polythene pots and carefully withdrawn with the cores. These cores were placed along a ruler $(300 \mathrm{~mm})$ and cut into small sections, $0-60,60-120$ and $120-180 \mathrm{~mm}$, respectively. All the cores of a profile (e.g. 0-60 mm) of the treatments were pooled and mixed, air-dried for $3 \mathrm{~h}$, and sieved. A $500 \mathrm{~g}$ of this, based on fresh weight and in triplicate were packed in 
small paper bags and sent to the laboratory for further processing and analysis. The approach was undertaken as described in various studies (Michael, P. S., 2020; Michael et al., 2015; Michael, P. S., 2018a, 2018b, 2018c; Michael et al., 2016, 2017; Michael, P.S., 2015, 2020).

\subsection{Measurement and analysis}

Triplicate samples from the surface $(0-60 \mathrm{~mm})$ and deep (120-180 mm) soils were used. The samples from 0-60 mm profile are hereafter referred to as surface soil and from the 120-180 mm profile as deep soil, respectively. The decision to use only the surface and deep soil data were necessary to clearly report the findings. $\mathrm{pH}$ was measured using a standard dilution ( $\mathrm{pH}$ meter (1:5 soil: water $\mathrm{w} / \mathrm{v})$ ) method (Michael et al., 2015; Michael et al., 2016, 2017).

$$
\left.\operatorname{SOC}(\%)=\left[\left(\left(W_{f}-F_{w}\right) \div W_{f}\right) \div C_{f}\right) \cdot 100\right]
$$

The soil organic carbon (SOC) content (\%) was estimated using the weight loss-on-ignition method (Schulte \& Hopkins, 1996). Five grams of the soil samples were placed in a crucible by weighing and heated in a muffle furnace for $12 \mathrm{~h}$ at $105^{\circ} \mathrm{C}$ to remove moisture $\left(\mathrm{W}_{\mathrm{f}}\right)$ and combusted again at $375^{\circ} \mathrm{C}$ for $17 \mathrm{~h}\left(\mathrm{~F}_{\mathrm{w}}\right)$, cooled for $2 \mathrm{~h}$ and weighed (Michael, P. S., 2019). The soil residue in the crucibles was combusted in a muffle furnace at $800^{\circ} \mathrm{C}$ for $12 \mathrm{~h}$, cooled for $2 \mathrm{~h}$, and reweighed. The SOC content was estimated by multiplying the carbon value by a conversion factor $\left(C_{f}\right)$ of 1.72 (Aipa \& Michael, 2018) and expressed as a percentage (Equation 1). Where SOC is the soil organic carbon content and 1.72 is a conversion factor $\left(C_{f}\right)$. The conversion factor was used to convert the OM content to organic carbon, assuming there was $58 \%$ carbon in the OM.

$$
\begin{aligned}
& \mathrm{SOC}_{\text {stock }}=\left[\left(\mathrm{SOC} \times \mathrm{BD} \times \mathrm{SP} \times \text { ha } \times \mathrm{C}_{\mathrm{f}}\right)\right] \ldots \ldots \ldots \ldots \ldots \ldots \ldots \ldots \ldots \ldots \ldots \ldots \ldots \ldots \ldots \ldots \\
& \mathrm{SOM}(\%)=\left[\left(\mathrm{SOC} \times \mathrm{C}_{\mathrm{f}}\right)\right] \ldots \ldots \ldots \ldots \ldots \ldots \ldots \ldots \\
& \mathrm{SOM}(\%)=\left[(\mathrm{SOC} \times \mathrm{BD} \times \mathrm{SP}) \times \mathrm{C}_{\mathrm{f}}\right] \ldots \ldots \ldots \ldots \ldots \\
& \operatorname{SOM}(\text { tonnes })=\left[(\mathrm{SOC} \times \mathrm{BD} \times \mathrm{SP} \times \mathrm{ah}) \mathrm{C}_{\mathrm{f}}\right]
\end{aligned}
$$

The size of the carbon stock ( $\mathrm{C}_{\text {-stock}}$ ) in each sampling profile (SP) was calculated as the sum of the individual carbon fractions $(\%) \times \mathrm{g} \mathrm{cm}^{-3} \times \mathrm{SP}(\mathrm{m})$ and expressed as a percentage (Equation 2). The soil organic matter (SOM) contents were estimated using the SOC contents and the $C_{f}$ as Equation 3. The SOM stock from the SOC to a certain SP was estimated as Equation 4. The weight of the SOM to a given SP and area was estimated as Equation 5. Where SOC, BD, SP (m) have been described above and area in hectare $\left(10,000 \mathrm{~m}^{2}\right)$, respectively.

The water holding capacity (WHC) was estimated as per Michael et al. (2015) by setting soil samples at $100 \%$ WHC after soaking in water and draining through a filter paper overnight (Michael \& Reid, 2018). These were weighed for the wet weight $\left(W_{w}\right)$ and dried in an oven at $105^{\circ} \mathrm{C}$ for $48 \mathrm{~h}$ and reweighed to obtain the oven-dry weight $\left(O D_{w}\right)$ using $W_{w}$ and $\mathrm{OD}_{\mathrm{w}}$. WHC was determined as Equation 6.

$$
\text { WHC }(\%)=\left[\left(\left(\mathrm{W}_{\mathrm{w}}-\mathrm{OD}_{\mathrm{w}}\right) \div O \mathrm{D}_{\mathrm{w}}\right) 100\right]
$$

$$
P=\left(1-\frac{B D}{d}\right) \times 100
$$

Bulk density $\left(\mathrm{g} \mathrm{cm}^{-3}\right)$ was calculated by oven drying of the cores at $105{ }^{\circ} \mathrm{C}$ for $48 \mathrm{~h}$ followed by re-weighing (Aipa \& Michael, 2018). The oven-dry weights were divided by the volume of the core and kept as the BD. Total porosity was determined as Equation 7 (Landon, 1991). $\mathrm{P}$ is total porosity (\%), BD is bulk density and $d$ is particle density equals to 2.65 $\mathrm{g} \mathrm{cm}^{-3}$.

Analyses for soil SOC, nitrogen, potassium, phosphorus, and magnesium were done at the University Analytical Service Laboratory using standard analytical procedures: Kjeldahl (Buchi K436 speed digester and Buchi K-350 Kjeldahl distillation unit) for nitrogen, OLSEN (Shimadzu 1800 UV/VIS spectrophotometer, Mettler Toledo, Model UV5Bio) for phosphorus and magnesium using ICP-OES (Spectro ARCOS brand) following $1 \mathrm{M} \mathrm{NH}_{4} \mathrm{Cl}$ extraction. Electrical conductivity was measured using a Direct Soil EC meter (Spectrum Technologies Inc., 12360 S Industrial Dr. East Plainfield, IL 60585 ) using solution (1:5 soil: water $w / v)$.

$$
m g=\left[\left(m E q \times A_{w}\right) \div V_{a}\right]
$$

Where possible, data in milliequivalent (mEq.100 $\mathrm{g}^{-1}$ soil) were converted to milligram $(\mathrm{mg})$ as Equation 8 (Michael, P. S., 2020). Where Aw is atomic weight measured in unified (u) and $V_{a}$ is valence of an atom measured in electrons $(e)$ (e.g. for nitrogen, $\mathrm{u}=14.0$ and $e=3$, as per the Octet rule).

\subsection{Statistical analysis}

The data were analyzed as we reported in various studies (Michael et al., 2015; Michael et al., 2016, 2017). The treatment averages of a profile of all the parameters (e.g. pH) were obtained by taking the mean of the three replicates $(n=3)$. To compare the treatment means, significant differences $(p \leq 0.05)$ between treatment means of each profile was determined by two-way ANOVA using statistical software JMPIN, AS Institute Inc., SAS Campus Drive, Cary, NC, USA 27513. If an interaction between the treatments and profile depths was found, one-way ANOVA with all combinations was performed using Tukey's HSD (honestly significant difference) and pairwise comparisons. In all the tables, the values presented are mean \pm standard error of three replicates $(n=3)$. An asterisk along the same row indicates a significant difference $(p \leq 0.05)$ between the control and the treatments at the same sampling profiles.

\section{Results}

\subsection{Effects on soil organic carbon}

Although a decrease in SOC was measured in all the treatments, the contents were within a range of $2-10 \%$ (Table 1), as expected in most soil. A significant loss in SOC measured was only in the planted soil, whereas in the other treatments the SOC contents were higher but lower than the control soil. The overall SOC content was control $>\mathrm{OM}+$ planted $>\mathrm{OM}>$ planted (Table 1). The sizes of the carbon stock per profile are shown in Tables 1 (\%) and Table $2\left(\mathrm{C} \mathrm{tha}^{-1}\right)$. The size of the carbon stock was less in the surface soil than in the deep profiles. In the surface of soil amended with OM, 18.9\% SOC was measured, equating to $62.76 \mathrm{t} \mathrm{Cha}^{-1}$ (Table 1 ). 
Table 1. The effects of organic matter and live plants on carbon stock, soil organic matter, water holding capacity, bulk density, and total porosity

\begin{tabular}{|c|c|c|c|c|c|c|c|c|}
\hline \multirow{3}{*}{ Soil Properties } & \multicolumn{8}{|c|}{ Sampling profile $(\mathrm{cm})$} \\
\hline & \multicolumn{4}{|c|}{$0-60$} & \multicolumn{4}{|c|}{$120-180$} \\
\hline & Control & OM & Planted & OM + Planted & Control & OM & Planted & OM + Planted \\
\hline Carbon Stock (t C ha ${ }^{-1}$ ) & $28.6 \pm 1.3$ & $62.8 \pm 1.1$ & $46.2 \pm 1.4$ & $59.4 \pm 1.6$ & $183.3 \pm 1.5$ & $107.7 \pm 1.4$ & $229.4 \pm 1.1$ & $182.7 \pm 1.2$ \\
\hline Soil Organic Matter (\%) & 6.79 & 6.06 & 5.63 & 6.39 & 7.39 & 5.83 & 5.67 & 5.92 \\
\hline Water holding capacity (\%) & $7.21 \pm 0.1$ & $32.38 \pm 0.2^{*}$ & $7.54 \pm 1.4$ & $21.91 \pm 1.2^{*}$ & $18.57 \pm 0.1$ & $33.09 \pm 0.3^{*}$ & $13.12 \pm 0.2^{*}$ & $16.87 \pm 1.5$ \\
\hline Bulk Density $\left(\mathrm{g} \mathrm{cm}^{-3}\right)$ & $0.67 \pm 2.1$ & $0.34 \pm 2.1$ & $0.76 \pm 2.1$ & $0.92 \pm 2.1$ & $0.78 \pm 2.1$ & $0.55 \pm 2.1$ & $1.31 \pm 2.1$ & $1.01 \pm 2.1$ \\
\hline Total Porosity (\%) & 75.14 & 87.12 & 71.20 & 65.11 & 71.16 & 79.34 & 50.35 & 62.13 \\
\hline
\end{tabular}

Table 2. Effects of organic matter and live plants on selected soil properties

\begin{tabular}{|c|c|c|c|c|c|c|c|c|}
\hline \multirow{3}{*}{ Soil Properties } & \multicolumn{8}{|c|}{ Sampling profile $(\mathrm{cm})$} \\
\hline & \multicolumn{4}{|c|}{$0-60 \mathrm{~cm}$} & \multicolumn{4}{|c|}{$120-180 \mathrm{~cm}$} \\
\hline & Control & OM & Planted & OM + Planted & Control & OM & Planted & OM + Planted \\
\hline $\mathrm{pH}$ & $6.0 \pm 0.1$ & $5.9 \pm 0.4$ & $6.1 \pm 0.6^{*}$ & $6.1 \pm 0.4^{*}$ & $5.9 \pm 0.3$ & $5.8 \pm 0.4$ & $6.1 \pm 0.6^{*}$ & $6.1 \pm 0.5^{*}$ \\
\hline Electrical Conductivity $\left(\mathrm{dSm}^{-1}\right)$ & $0.05 \pm 0.2$ & $0.12 \pm 0.2^{*}$ & $0.05 \pm 0.4$ & $0.08 \pm 0.2^{*}$ & $0.07 \pm 0.3$ & $0.13 \pm 0.3^{*}$ & $0.04 \pm 0.1$ & $0.04 \pm 0.4 *$ \\
\hline Total Nitrogen (\%) & 0.45 & $0.32 *$ & $0.33^{*}$ & $0.33^{*}$ & 0.26 & $0.35^{*}$ & $0.32 *$ & $0.34^{*}$ \\
\hline Phosphorus (mg kg $\left.{ }^{-1}\right)$ & $48.47 \pm 0.4$ & $68.48 \pm 0.5$ & $71.35 \pm 0.4$ & $58.38 \pm 0.3$ & $58.86 \pm 0.2$ & $71.60 \pm 0.2$ & $59.67 \pm 0.3$ & $65.79 \pm 0.4$ \\
\hline Available Potassium (mEg. $100 \mathrm{~g}^{-1}$ ) & $1.32 \pm 0.2$ & $2.75 \pm 0.2^{*}$ & $1.38 \pm 0.3$ & $2.66 \pm 0.2^{*}$ & $1.25 \pm 0.1$ & $2.83 \pm 0.3^{*}$ & $1.15 \pm 0.1$ & $2.36 \pm 0.2^{*}$ \\
\hline Available Magnesium (mEg. $100 \mathrm{~g}^{-1}$ ) & $3.96 \pm 0.3$ & $3.91 \pm 0.5$ & $3.50 \pm 0.2 *$ & $4.00 \pm 0.3$ & $4.02 \pm 0.4$ & $3.98 \pm 0.3$ & $3.79 \pm 0.4^{*}$ & $4.07 \pm 0.5$ \\
\hline
\end{tabular}


Planting in soil amended with OM had a carbon stock of $46 \%$, resulting in $46.23 \mathrm{t} \mathrm{Cha}^{-1}$. The biggest increase of $59.4 \mathrm{t} \mathrm{Cha}^{-1}$ $(59.4 \% \mathrm{C})$ was measured when OM and live plants co-existed. In the deep soil, $35.9 \%$ SOC, which is $107.8 \mathrm{t} \mathrm{C} \mathrm{ha}^{-1}$, was present in the soil amended with OM. In this profile, more carbon was present in the planted soil without amendment (Table 1). In all the treatments, OM addition along or planting in soil without the OM amendment resulted in lower SOM. The SOM content in the amended soil and planted was nearly the same as in the control treatment. The overall changes in $\mathrm{SOM}$ was control $>\mathrm{OM}+$ planted $>\mathrm{OM}>$ planted (Table 1 ).

\subsection{Effects on water holding capacity}

The WHC of the control soil ranged from 7-19\% from the surface to deep soil, respectively (Table 1 ). When OM was applied, the WHC was increased by nearly $25 \%$ at the surface and by $14 \%$ at the deep soil, with the changes in the planted soil being lower than the amended and planted soils (Table 1). The data presented in Table 1 demonstrated that the addition of OM improved the WHC of sandy soil and planting in the absence of OM lowered it. For example, WHC in soil planted without OM application was nearly the same or lower as the control, which when applied and planted, increased but remained lower than the amended without plants. Overall changes in $\mathrm{WHC}$ are $\mathrm{OM}>\mathrm{OM}+$ planted $>$ planted $>$ control (Table 1).

\subsection{Effects on bulk density}

The bulk density (BD) of the natural soil from which the soil used in the study was obtained is near $1.2 \mathrm{~g} \mathrm{~cm}^{-3}$ under $I$. cylindrica and near $0.3 \mathrm{~g} \mathrm{~cm}^{-3}$ under Leucaena leucocephaha (Michael, P. S., 2019). Compared to these, BD of the control soil was within the range of $0.7-0.8 \mathrm{~g} \mathrm{~cm}^{-3}$, decreased when OM was applied to within a range of $0.3-0.6 \mathrm{~g} \mathrm{~cm}^{-3}$ (Table 1). The opposite happened when planted or OM was applied and planted. Planting in the absence of OM or plants co-existing with OM increased the BD, more so at the deeper soil. The BD at the deep and wetter soil was higher, supporting the higher WHC and decrease in P (Table 1).

Table 1 shows $P$ estimated using Equation 7 and was decreasing from the surface to the deep soils in all the treatments. The significant decreased in $\mathrm{P}$ was such that in the planted soil without the OM amendment was by $21 \%$, followed by $8 \%$ in the amended soil without plants, $4 \%$ in the control, and by $3 \%$ in the amended and planted soils, respectively (Table 1 ). The decrease in $\mathrm{P}$ in the planted soil corresponded to the high BD measured (Table 1). Generally, $\mathrm{OM}$ addition alone significantly decreased $\mathrm{P}$, e.g. decrease in $12 \%$ at the surface soil to $8 \%$ in the deep soil, respectively. An appreciable amount of native SOM was present in the control soil (Table 1). Compared to that, the surface and deep SOM contents decreased when OM was applied, the changes ranging from $0.2-3.8 \%$. In general, the presence of plants further decreased the SOM content by $2.1-2.9 \%$ (Table 1 ).

\subsection{Effects on $\mathrm{pH}$}

The changes in $\mathrm{pH}$ measured are shown in Table 2, and the control soil $\mathrm{pH}$ was near 6 units. Application of OM alone without planting decreased the $\mathrm{pH}$, with the changes induced ranging from 5.9 units within the surface profile to 5.8 units at the deep profile, respectively. In the soil without OM where the sweet potato was planted, $\mathrm{pH}$ narrowly increased by just 0.1 units throughout the sampling profiles. The changes in $\mathrm{pH}$ were the same in the soil $\mathrm{OM}$ and plants were co-existing. These changes, in general, were within the soil $\mathrm{pH}$ requirement range of sweet potato, 6.0-6.5 units, and most plants strive within a $\mathrm{pH}$ range of $5.5-7.0 \mathrm{pH}$ units.

\subsection{Effects on electrical conductivity}

The changes in electrical conductivity (EC) are shown in Table 2. The changes in the control soil ranged from between 0.05-0.07 dSm ${ }^{-1}$. Compared to all the treatments, the EC of the soil amended with $\mathrm{OM}$ and without live plants was higher at all the sampling profiles. The addition of OM lowered the $\mathrm{EC}$ but when live plants were present, EC was only high within the surface, and the increase was only by $0.05 \mathrm{dSm}^{-1}$. The overall changes measured were $\mathrm{OM}>$ control $>$ planted $>$ OM+planted (Table 2).

\subsection{Effects on total nitrogen}

Total nitrogen (ammonia, organic and reduced nitrogen, and nitrate-nitrite) was measured to assess the nitrogen status of the sandy loam soil. On the surface, all the treatments lowered the nitrogen contents, and more so by application of OM addition (Table 2). In the deep soil, the opposite happened. Organic matter application, planting, and co-existence of $\mathrm{OM}$ and plants increased the nitrogen content, the contribution being higher by OM. The decrease in nitrogen content in the surface soil was $\mathrm{OM}>$ planted $>\mathrm{OM}+$ planted $>$ control, whereas, in the deep soil, the increase was $\mathrm{OM}>\mathrm{OM}+$ planted $>$ planted $>$ control (Table 2).

\subsection{Effects on available phosphorus}

The available phosphorus measured are shown in Table 2. The phosphorus content of the control soil was nearly the same throughout the sampling profiles (Table 2). In the surface soils, the OM amendment and planting without amendment increased the phosphorus content by nearly $85 \%$. OM addition and planted did not affect surface soil phosphorus. In the deep soils, OM addition alone or followed by planting significantly increased available phosphorus than by plants alone. In general, more phosphorus was added in the surface soil by plants existing alone, as was by OM addition in the deep soils (Table 2).

\subsection{Effects on available potassium}

The available potassium content of the control soil clearly indicated that the sandy soil was low in potassium (Table 2). The low status of this nutrient was significantly improved when OM was added, increasing the content by nearly $50 \%$. Potassium availability in the soil without $\mathrm{OM}$ and plants was nearly the same as the control soil, compared to the OM amended soil and planted, which was almost as high as the OM amended soil without plants (Table 2). Generally, plants added a small amount of potassium to the soil, as much as that by the OM alone, thereby increasing its availability. 
Within the surface soil, $1.3 \mathrm{mEq} .100 \mathrm{~g}^{-1}$ soil (that is $50.7 \mathrm{mg}$ ) was measured, which increased to $1.4 \mathrm{mEq} .100 \mathrm{~g}^{-1}$ soil $(54.6$ $\mathrm{mg}$ ) in the soil planted with sweet potato. The overall increase in available potassium was $\mathrm{OM}>\mathrm{OM}+$ planted $>$ planted $>$ control (Table 2).

\subsection{Effects in available magnesium}

The changes in available magnesium are shown in Table 2. The existence of OM or plant alone decreased the soil magnesium content with the significant reduction measured in the planted soil. When OM was applied and planted, the magnesium content was high throughout the sampling profiles (Table 2). These changes were such that OM addition alone decreased the magnesium content by $4.1 \mathrm{mEq} .100 \mathrm{~g}^{-1}$ soil $\left(48.82 \mathrm{mg}\right.$ ) and by $3.8 \mathrm{mEq} .100 \mathrm{~g}^{-1}$ soil $(46.17 \mathrm{mg})$ at the deep soil (Table 2). When the soil was amended with OM and planted, the magnesium content was $4 \mathrm{mEq} .100 \mathrm{~g}^{-1}$ soil (48.6 $\mathrm{mg}$ ) which increased to $4.1 \mathrm{mEq} .100 \mathrm{~g}^{-1}$ soil (49.82 mg).

\section{Discussion}

The changes in soil physiochemical properties caused by OM addition, planting without OM or OM, and plants coexisting in sandy loam soil mounds measured are shown in Table 1 and Table 2. The addition of OM, planting without OM addition, or co-existence of $\mathrm{OM}$ and plants all resulted in lowering of the SOC, and more so in the planted soil without OM addition (Table 1). These indicated that contribution by live plants was important for supplementing of SOC already in the soil, in addition to the OM applied. Comparatively, the coexistence of OM and live plants increased the SOC content by a little bit, even if lower than the content of the control, e.g. by $0.3 \%$ at the surface and $0.1 \%$ at the deep soil, respectively, pointing out that the live plants contributed to the SOC content. The decrease in SOC in the planted soils, however, was attributed to the carbon use by plants. The decrease in SOC (Table 1 ) resulted in a loss of $0.2-3.8 \%$ SOM, which was estimated to be $17.7 \mathrm{t} \mathrm{Cha}^{-1}$ in the presence of live plants. In the amended soil, the co-existence of $\mathrm{OM}$ and live plants decreased the SOM content by $0.7 \%$, (Table 1 ), nearly $2 \%$ lower than in the planted soil. These results are an indication of general carbon use by microbial ecology and plants, as pointed in various studies (Michael et al., 2015). The decrease in SOC in the OM amended soil occurred because of microbial oxidation of the addition and carbon use from the recalcitrant pool for energy needs (Jiang et al., 2014).

The results showed OM addition alone or planting in the amended soil improved the WHC by $30 \%$, and planting in soil without OM lowered it (Table 1). These results pointed out that microbial decomposition of OM is sufficient to enhance moisture retention, regardless of the OM type, e.g. Cogon grass materials, whereas plants deleted it, important implications for general sandy loam soil use. In addition, WHC correlated with the changes in SOC, a strong indication that the latter influenced WHC. The BD was affected by OM addition in soil without plants (Table 1 ) and was significantly improved when planted, whether OM was available or not to values $>1.5 \mathrm{~g} \mathrm{~cm}^{-3}$ desirable for plant growth (Hunt \& Gilkes, 1992). An increase in BD, in general, resulted in a decrease in porosity (Table 1), agreeing to established findings of previous studies (Shakir \& Razzaq, 2002). Unfortunately, OM addition resulted in a decrease in $\mathrm{pH}$, compared to the planted soils (Table 2), contradicting the changes in $\mathrm{pH}$ induced by the addition of OM of varying nitrogen content in extremely acidic $(\mathrm{pH}<4)$ or highly alkaline $(\mathrm{pH} \geq 6)$ soils of acid sulfate soils we reported (Michael et al., 2015; Michael et al., 2016, 2017) and in other soil types (Muktamar et al., 2020). Further, the nitrogen content of the OM amended soil (see Table 2) at the two sampling profiles were low, a strong indication that the Cogon grass material used was low in nitrogen, the main reason the $\mathrm{pH}$ decreased. In contrast to the effects on $\mathrm{BD}$ and $\mathrm{pH}, \mathrm{OM}$ addition significantly increased the EC to values conducive for plant growth (Table 2), demonstrating that decomposition of the OM resulted in release and availability of nutrients, e.g. the high potassium and phosphorus contents measured (e.g. Table 2). These nutrients were used by the live plants for growth, e.g. removal of potassium (shown in Table 2), as shown by the lower EC values measured in the soils without amendment and planted (Table 2).

Table 2 shows live plants depleted nitrogen, potassium, and magnesium in soil without OM, compared to the phosphorus contents. One possible explanation for this could be that sweet potato plants require nitrogen, potassium, and magnesium more than phosphorus at the early stages (45 days) of growth and development (Parvage et al., 2013). Hughes et al. (2009) reported the main nutritional requirement of the sweet potato is potassium, supporting the reason why the potassium content was the lowest (Table 2). These researchers further showed phosphorus requirement is the lowest, supporting why a high amount of its availability was measured (Table 2). OM amendment (or co-existence) with live plants increased potassium content by $55.9 \mathrm{mg}$ in the surface and $61.8 \mathrm{mg}$ in the deep soil (Table 2), respectively, evidence of potassium being added from the decomposition of OM.

The overall results are in agreement that nitrogen, potassium, and magnesium are needed by sweet potato plants at the vegetative stage (e.g. 45 days as in this study) (Xiong et al., 2014), and phosphorus, maybe during tuber formation (later stages of growth). Young plants, such as the 45 days old sweet potato plants need nitrogen as a major component of chlorophyll and amino acids for active growth and require potassium to regulate the stoma (Mårtensson \& Witter, 1990). Magnesium was significantly depleted in the planted soil without OM (Table 2), indicating there was an active uptake, supported by findings of (Al-Esailyl \& El-Naka, 2013) that magnesium increased plant growth characteristics and photosynthetic activities of the crop. In the surface soil, $14.2 \mathrm{mg}$ of magnesium was removed, compared to a lesser amount, $9.7 \mathrm{mg}$, in the deep soil (Table 2), strongly suggesting that magnesium is highly needed by sweet potato plants.

\section{Conclusion}

Organic matter addition in composted mounds is a realistic approach to manage nutrient leaching, retain moisture, establish suitable microbial ecology, and alter soil properties important for crop production. This study showed co-existence of $\mathrm{OM}$ with live sweet potato plants in 
composted mounds is important for the management of sandy loam soil fertility, without which the crop depletes SOC, total nitrogen, available potassium, and magnesium. Cogon grass materials addition as organic matter improved most of the soil physiochemical properties to levels desirable to support the normal growth and development (production) of the crop.

\section{Declaration of Competing Interest}

The authors declare no competing financial or personal interests that may appear and influence the work reported in this paper.

\section{References}

Aipa, J, \& Michael, P. S. (2019). Different land-use system improves soil fertility status of sandy soil and increases the yield of rice under rain-fed wet tropical lowland conditions in Papua New Guinea. Int J Agric Environ Res, 5, 19-27.

Aipa, James, \& Michael, P. S. (2018). Poultry manure application and fallow improve peanut production in sandy soil under continuous cultivation. International Journal of Environmental and Agriculture Research, 4(2).

Al-Esailyl, I. A., \& El-Naka, E. A. (2013). Effects of magnesium and humic acid on the productivity of sweet potato grown in sandy soil. Egypt Journal of Applied Science, 28, 615-633.

D'Souza, E., \& Bourke, R. M. (1982). Compost increases sweet potato yields in the highlands. Harvest, 8(4), 171-175.

Floyd, C. N., Lefroy, R. D. B., \& D'souza, E. J. (1988). Soil fertility and sweet potato production on volcanic ash soils in the highlands of Papua New Guinea. Field Crops Research, 19(1), 1-25.

Hughes, M. J., Coleman, E. A., Taraken, I. T., \& Igua, P. (2009). Sweetpotato agronomy in Papua New Guinea. Soil Fertility in Sweetpotato-Based Cropping Systems in the Highlands of Papua New Guinea (Edited by G. Kirchhof). ACIAR Technical Report, 71, 12-23.

Hunt, N., \& Gilkes, R. (1992). Farm monitoring handbook.

Jiang, X., Cao, L., \& Zhang, R. (2014). Changes of labile and recalcitrant carbon pools under nitrogen addition in a city lawn soil. Journal of Soils and Sediments, 14(3), 515524.

Landon, J. R. (1991). Booker tropical soil manual: a handbook for soil survey and agricultural land evaluation in the tropics and subtropics. Longman Scientific \& Technical.

Mårtensson, A. M., \& Witter, E. (1990). Influence of various soil amendments on nitrogen-fixing soil microorganisms in a long-term field experiment, with special reference to sewage sludge. Soil Biology and Biochemistry, 22(7), 977-982.

Michael, P. S. (2020). Simple carbon and organic matter addition in acid sulfate soils and time-dependent changes in $\mathrm{pH}$ and redox under varying moisture regimes. Asian Journal of Agriculture, 4(1).

Michael, P. S. (2019). Roles of Leucaena leucocephala on sandy loam soil $\mathrm{pH}$, bulk density, water-holding capacity, and carbon stock under humid lowland tropical climatic conditions. Bull J Soil Sci, 4, 33-45.
Michael, P. S., Fitzpatrick, R., \& Reid, R. (2015). The importance of organic matter on amelioration of acid sulfate soils with sulfuric horizons. Geoderma, 225, 4249.

Michael, P. S. (2018a). Comparative analysis of the ameliorative effects of soil carbon and nitrogen amendment on surface and subsurface soil pH, Eh, and sulfate content of acid sulfate soils. Eurasian Soil Science, 51, 1181-1190.

Michael, P. S. (2018b). Effects of live and dead plant matter on the stability of $\mathrm{pH}$, redox potential, and sulfate content of sulphuric soil material neutralized by addition of alkaline sandy loam. Malaysian Journal of Soil Science, 22, 1-18.

Michael, P. S. (2018c). The Roles of Surface Soil Carbon and Nitrogen in Regulating the Surface Soil pH and Redox Potential of Sulfidic Soil Materials of Acid Sulfate Soils. Pertanika Journal of Tropical Agricultural Science, 41(4).

Michael, P. S, Fitzpatrick, R. W., \& Reid, R. J. (2016). The importance of soil carbon and nitrogen for amelioration of acid sulphate soils. Soil Use and Management, 32(1), 97-105.

Michael, P. S., Fitzpatrick, R. W., \& Reid, R. J. (2017). Effects of live wetland plant macrophytes on acidification, redox potential and sulphate content in acid sulphate soils. Soil Use and Management, 33(3), 471-481.

Michael, P. S., \& Reid, J. R. (2018). The combined effects of complex organic matter and plants on the chemistry of acid sulfate soils under aerobic and anaerobic soil conditions. Journal of Soil Science and Plant Nutrition, 18, 542-555.

Michael, P. S. (2015). Effects of alkaline sandy loam on sulfuric soil acidity and sulfidic soil oxidation. International Journal of Environment, 4(3), 42-54.

Michael, P. S. (2020). Cogon grass biochar amendment and Panicum coloratum planting improve selected properties of sandy soil under humid lowland tropical climatic conditions. Biochar, 2(4), 489-502.

Muktamar, Z., Lifia, L., \& Adiprasetyo, T. (2020). Phosphorus availability as affected by the application of organic amendments in Ultisols. SAINS TANAH-Journal of Soil Science and Agroclimatology, 17(1), 16-22.

Parvage, M. M., Ulén, B., Eriksson, J., Strock, J., \& Kirchmann, H. (2013). Phosphorus availability in soils amended with wheat residue char. Biology and Fertility of Soils, 49(2), 245-250.

Pérez-Piqueres, A., Edel-Hermann, V., Alabouvette, C., \& Steinberg, C. (2006). Response of soil microbial communities to compost amendments. Soil Biology and Biochemistry, 38(3), 460-470.

Schulte, E. E., \& Hopkins, B. G. (1996). Estimation of soil organic matter by weight loss-on-ignition. Soil Organic Matter: Analysis and Interpretation, 46, 21-31.

Schulz, H., \& Glaser, B. (2012). Effects of biochar compared to organic and inorganic fertilizers on soil quality and plant growth in a greenhouse experiment. Journal of Plant Nutrition and Soil Science, 175(3), 410-422. 
Shakir, M. S., \& Razzaq, A. (2002). Effect of salts on bulk density, particle density, and porosity of different soil series. Asian Journal of Plant Sciences.

Taraken, I. T., \& Ratsch, R. (2009). Sweetpotato cultivation on composted mounds in the highlands of Papua New Guinea. Soil Fertility in Sweetpotato-Based Cropping Systems in the Highlands of Papua New Guinea, 24-32.

Tilston, E. L., Pitt, D., \& Groenhof, A. C. (2002). Composted recycled organic matter suppresses soil-borne diseases of field crops. New Phytologist, 154(3), 731-740.

Tiquia, S. M. (2010). Reduction of compost phytotoxicity during the process of decomposition. Chemosphere, 79(5), 506-512.

Tiquia, S. M., Tam, N. F. Y., \& Hodgkiss, I. J. (1996). Microbial activities during composting of spent pig-manure sawdust litter at different moisture contents. Bioresource Technology, 55(3), 201-206.
Tuitert, G., Szczech, M., \& Bollen, G. J. (1998). Suppression of Rhizoctonia solani in potting mixtures amended with compost made from organic household waste. Phytopathology, 88(8), 764-773.

Tuomela, M., Vikman, M., Hatakka, A., \& Itävaara, M. (2000). Biodegradation of lignin in a compost environment: a review. Bioresource Technology, 72(2), 169-183.

Weber, J., Karczewska, A., Drozd, J., Licznar, M., Licznar, S., Jamroz, E., \& Kocowicz, A. (2007). Agricultural and ecological aspects of sandy soil as affected by the application of municipal solid waste composts. Soil Biology and Biochemistry, 39(6), 1294-1302.

Xiong, Y., Zeng, H., Xia, H., \& Guo, D. (2014). Interactions between leaf litter and soil organic matter on carbon and nitrogen mineralization in six forest litter-soil systems. Plant and Soil, 379(1-2), 217-229. 